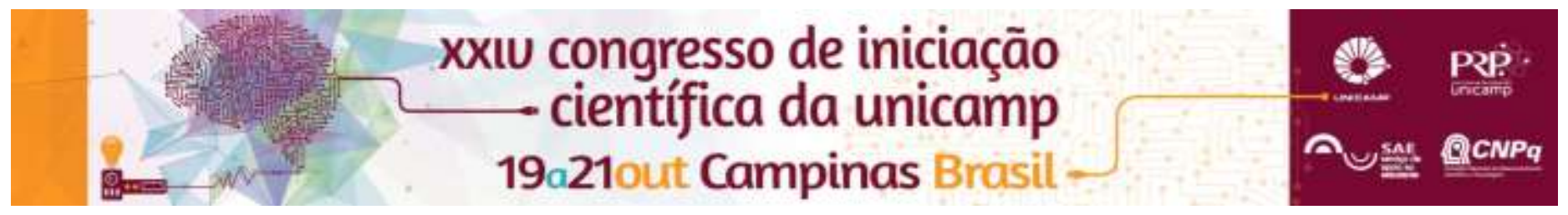

\title{
Análise de projetos do programa Case Study Houses por meio de modelos físicos e virtuais
}

\section{LUIZ FELIPE NASCIMENTO DOS REIS}

\section{Resumo}

O objeto desta pesquisa são três projetos residenciais modernos pertencentes ao programa Case Study Houses da Califórnia, concebidos a partir da ideia de projeto modulado e pré-fabricado, no período do pós-segunda guerra. O objetivo do estudo é de investigar e relacionar os projetos a partir da elaboração de modelos físicos e virtuais, focando na análise do projeto de interiores e sua relação com o projeto do edifício. A investigação será feita no sentido de se compreender o projeto de interiores e sua relação com a forma e espaço dos projetos arquitetônicos.

Palavras-chave: Case Study Houses, Interiores, Análise por modelos e maquetes.

\section{Introdução}

Especialmente a partir de 1945 nos Estados Unidos, houve então uma mudança de paradigma entre os arquitetos e seus projetos de residências. Ornamentos, espaços e elementos considerados excessivos ou supérfluos foram deixados para trás tornando a arquitetura residencial muito mais prática, funcional, com soluções econômicas e mais apropriadas para a família da sociedade daquela época.

Como observou Esther Mc Coy (1962, p.4) estes projetos demonstraram que uma boa casa poderia ser realizada como materiais econômicos, além de não haver a necessidade de vários banheiros e muita área. $O$ projeto de interiores e de paisagismo também foi grande protagonista da popularidade das Case Studies.

The interiors were also revolutionary. All the houses (...) had lightweight chairs, sofás and tables with bases or frames of steel rods, and for the patios metal-tubing-and-cord chairs and chaises, or butterfly chairs of steel rod and canvas. (The lightweight, movable pieces were symbolic of a generation which had acquired mobility during the war years (1962, p.4).

Os projetos de interiores das Case Study estavam em sintonia com a linguagem da arquitetura do edifício. Mobiliário móvel e leve, com materiais semelhantes aos próprios materiais adotados na construção como o aço e vidro. A madeira compensada curvada a quente em alguns casos, plástico e derivados. A leveza e continuidade espacial predominavam nos projetos destas casas. Objetos de design desenhados para este novo modelo de casa moderna também são elementos que se destacam nos interiores das Case Studies.

Além disso, o programa Case Study promoveu e estimulou o design de objetos em escala maior. Pequenas fábricas concebidas pelos designers e arquitetos do programa se encarregavam de desenhar os objetos da vida moderna concebida pelo programa. O mais conhecido foi o estúdio de Charles e Ray Eames (Koenig, 2005).

Equipamentos e eletrodomésticos industrializados faziam parte deste contexto da vida moderna da sociedade industrial. Como observa Witold Rybczynski (1999) após 1900 aparelhos domésticos como aspiradores de pó, ventiladores, máquinas de lavar roupas tornaram-se mais comuns nas casas. Em 1927 mais de 60\% das casas americanas tinham eletricidade, fato que alterou os espaços da casa moderna.

\section{Resultados e Discussão}

A pesquisa foi realizada a partir de levantamento de bibliografia, leituras, análise por desenhos, modelos de investigação virtuais.

Os modelos virtuais foram desenvolvidos em Autodesk Revit, o que possibilitou uma investigação profunda quanto a materiais e técnicas construtivas empregadas.

A partir de "Por uma Arquitetura" de Corbusier foi observado o emprego da modularidade e da fabricação de casas em série como prática política, ideológica. Dado tal panorama - que se perpetua durante todo o período moderno - as escolas francesa (encabeçada pelo próprio Corbusier) e alemã (decorrente da emblemática Bauhaus) extrapolam a temática para além da academia, atingindo em 1945 a revista Arts \& Architecture com seu programa Case Study Houses. Sob a sombra da Segunda Grande Guerra os estudos se concretizam em 36 projetos de Arquitetura.

\section{Conclusões}

O emprego de materiais e técnicas anteriormente restritas a grandes edifícios se aplica às casas do projeto graças aos avanços da indústria - que de alguma forma acompanhou o setor bélico. Aliados às belas cores e novas formas de se mobiliar uma casa, perfis metálicos, grandes lâminas de vidro e o concreto armado se perpetuam e se eternizam como grandes símbolos do modernismo. O minimalismo e o conceito de programa se consolidam e se eternizam através das obras do programa $\mathrm{CSH}$.

\section{Agradecimentos}

Antes de mais nada parabenizo e agradeço ao $\mathrm{CNPq}$ pela oportunidade. Agradeço à minha mãe por todo o apoio durante esses vinte e um anos de existência; à minha orientadora, professora Ana. Por fim, duas inspirações: os arquitetos Oscar Niemeyer e João Paulo Daolio - este também parte de minha educação enquanto arquiteto.

KOENIG, Gloria. Eames. New York: Taschen, 2005.

McCOY, Esther. Case Study Houses 1945-1962. Los Angeles: Hennessey+Ingalls, 1962.

SMITH, Elizabeth A.T. Case Study Houses. Madrid: Taschen, 2006. CORBUSIER, L. Por uma Arquitetura. Brasil: Perspectiva. 2014 